\title{
Precursors and consequences of youth poverty in Germany
}

\author{
Olaf Groh-Samberg \\ ogs@bigsss-bremen.de - University of Bremen
}

(Received December 2013 Revised April 2014)

http://dx.doi.org/10.14301/llcs.v5i2.281

\begin{abstract}
We examine time trends, precursors and continuity of poverty during youth and young adulthood in Germany. Although Germany's labour market performed well during the recent economic crisis, this occurred against the backdrop of growing social inequality and strong increase in the risk of poverty, especially among youth and young adults. Based on data from the German Socio-Economic Panel Study, we propose a method to take into account inter-generational support by virtually pooling the income of residentially independent children and their parents. We show that poverty risks are differentially related to the "big five" transitions to adulthood. Leaving the parental home and entering unemployment strongly increase poverty risks, whereas cohabitation and employment in the higher labour market segments are strong protectors against poverty. The transition to parenthood, educational participation and precarious employment are not consistently related to poverty risk once inter-generational support is taken into account. While enrollment at university has a positive impact on poverty when residentially independent children are considered economically independent, this effect disappears with adjustment for parental resources. Whereas the impact of youth transitions does not change over time, social background has a strong and increasing impact on poverty risks. Social background and poverty experiences during youth strongly affect poverty risks later in life, although life course continuity weakens through the period of youth transitions. Overall, these results clearly point towards the increasing importance of social background and inequality in affecting the risk of poverty during the transition to adulthood.
\end{abstract}

Keywords: Youth transitions, poverty, life course, inter-generational transmission, Germany, Great Recession, SOEP

\section{Introduction}

In considering the impact of the recent Great Recession on youth and young adults, Germany clearly stands out as an exceptional case (Scarpetta, Sonnet \& Manfredi, 2010; Cahuc, Carcillo, Rinne \& Zimmermann, 2013; Bell \& Blanchflower, 2011). Whereas youth unemployment skyrocketed in many European countries, and increased to a lesser extent in the U.S., Germany experienced a decline. Germany's decline in the youth unemployment rate paralleled an overall positive trend in the labour market. Although economic growth rates elsewhere were sharply hit by the Great Recession, the German labour market performed extraordinary well, giving rise to "another economic miracle" (Rinne and Zimmermann, 2011).

However, as far as youth and young adults are concerned, this picture of only marginal impact of the Great Recession in Germany is only half of the story. The other half is that almost no other OECD country has experienced an increase of poverty rates that compares to the German case, in the short period between the end of the last millennium and the advent of the Great Recession 
(Grabka \& Frick, 2013; OECD, 2008, 2011; Keeley \& Love, 2010). Even more striking, in no other age group did poverty rates increase so much as in the age group between 18 and 25 years (see Figure 3 below). Youth and young adults now comprise the age group with the highest poverty rates in Germany; this was not the case a decade ago. This steep increase in youth poverty in Germany has received little attention from the general public and in the social sciences (Grabka \& Frick, 2010; Reinowski \& Steiner, 2006).

This paper proceeds in five parts: in the following section (2) we provide a brief overview of changes in youth transitions, setting the context for increasing poverty risks. Next we describe the data and measurements (3). We also introduce an adjusted measure of poverty that accounts for the potential inter-generational support of children who have moved out of the parental home (4). We then (5) provide a brief descriptive overview of poverty trends in Germany, focusing on the age range between 15 and 30 . In section 6 we analyze the precursors of poverty by means of regression analysis. Section 7 addresses the life-course consequences of youth poverty. Section 8 concludes.

\section{Changing youth transitions in Germany}

The increase of youth poverty is embedded in ongoing social changes characterizing the transitions from youth to adulthood (Blossfeld, Buchholz, Bukodi \& Kurz, 2008; Kurz, Steinhage \& Golsch, 2005). Educational expansion has led to a prolongation of education in young adults' lifecourses, and complex trends have led to a weakening of the traditionally strong coupling between the vocational training system (the so called "dual system") and the labour market in Germany. Ever more young people are entering the so-called "transition system" that does not provide approved vocational certificates (Baethge, Solga \& Wieck, 2007). In turn, labour market entry has become increasingly difficult during the past decades (Buchholz \& Kurz, 2008; Giesselmann, 2009). This is not only attributable to changes in the vocational system, but also due to structural changes in the German labour market, resulting in a large increase in low-paid and precarious jobs (Giesecke \& Heisig, 2011; Giesselmann \& Lohmann, 2008), tightened competition and intensification of work (i.e., working longer and harder; see Lenhardt \& Priester, 2005), and a marked decline of tenure (Diewald \& Sill, 2004). With the extensive labour market reforms introduced between 2002 and 2004, the precarious segment of the labour market expanded greatly. From 2000 to 2005, unemployment rates increased sharply in Germany and then declined rapidly. However, this decline was not accompanied by an increase in regular employment but rather by increasing numbers of precarious jobs, including part-time and marginal employment.

Trends in participation in education and work for young adults aged 20-30 years are summarized in Figure 1 . On the one hand, we see educational expansion resulting in a steady increase in the proportion of young adults enrolled at university (including the universities of applied sciences). The share of young people in vocational training is increasing as well, but this share includes those enrolled or even trapped in the so called "transition system". The share of young adults who are not in the labour market and not in education or training is decreasing over time. This might be due to a decrease of young mothers and housewives. On the other hand, we see increasing difficulties in the labour market, indicated by rising unemployment and precarious employment. We use a composite measure of labour market segmentation that is described in more detail in the data section below (see section 3 ). Whereas more than $50 \%$ of the young adults were employed in the higher or intermediate labour market segment in 1995, this share has declined to almost $40 \%$ in 2012 , with the strongest decline for employment in the higher labour market segment. 
Figure 1. Trends in educational enrollment and labour market participation of 20-30 year olds

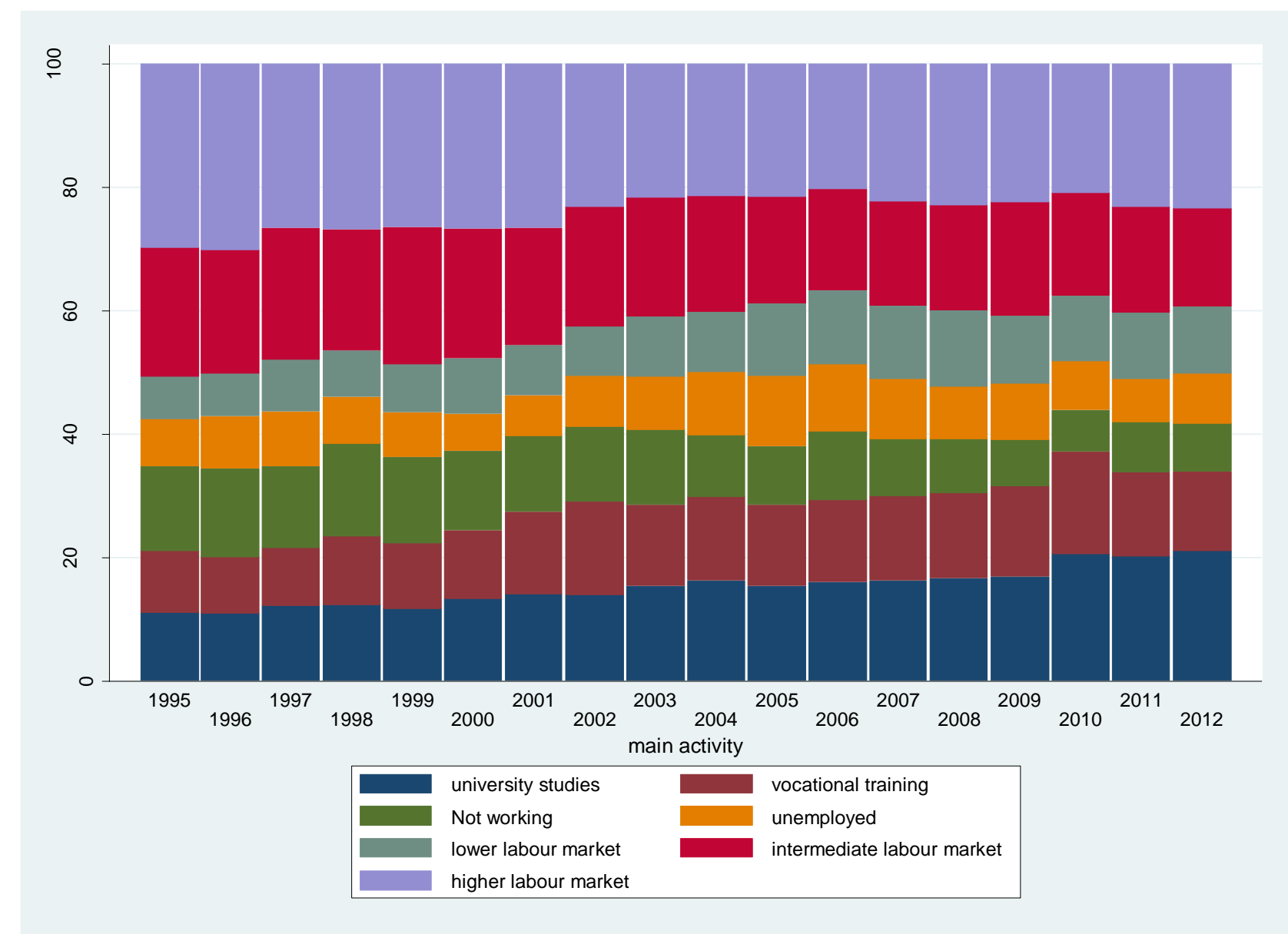

SOEPV29, 1995-2012, weighted results.

At the same time, a secular trend towards prolongation of adolescence and post-adolescence has led to a postponement and diversification of the transition to independent living and family formation (Scherger, 2009). There is empirical evidence that the postponement of family formation is at least partly due to increased labour market insecurity (Gebel \& Giesecke, 2009; Düntgen \& Diewald, 2007). This is particularly true for highly qualified women seeking to enter into higher segments of the labour market before childbirth. However, for less qualified women with poor labour market prospects, unemployment or precarious employment can trigger early childbirth (Düntgen \& Diewald, 2007). In general, changing gender roles and female labour market participation challenge the traditional "male breadwinner model" of the German welfare state (Gottschall \& Bird, 2003) and pose new threats to the reconciliation of work and family. As a consequence, fertility rates have declined rapidly in Germany, ranking among the lowest fertility countries in the OECD world (Population Reference Bureau, 2013).

Figure 2 summarizes these changes. The last 20 years have seen a strong decline in the share of 20 to 30 year old young adults who have already built their own families. A growing proportion is either still living with their parents or is living in single households. ${ }^{1}$ 


\section{Figure 2. Trends in living arrangements of $\mathbf{2 0 - 3 0}$ year olds}

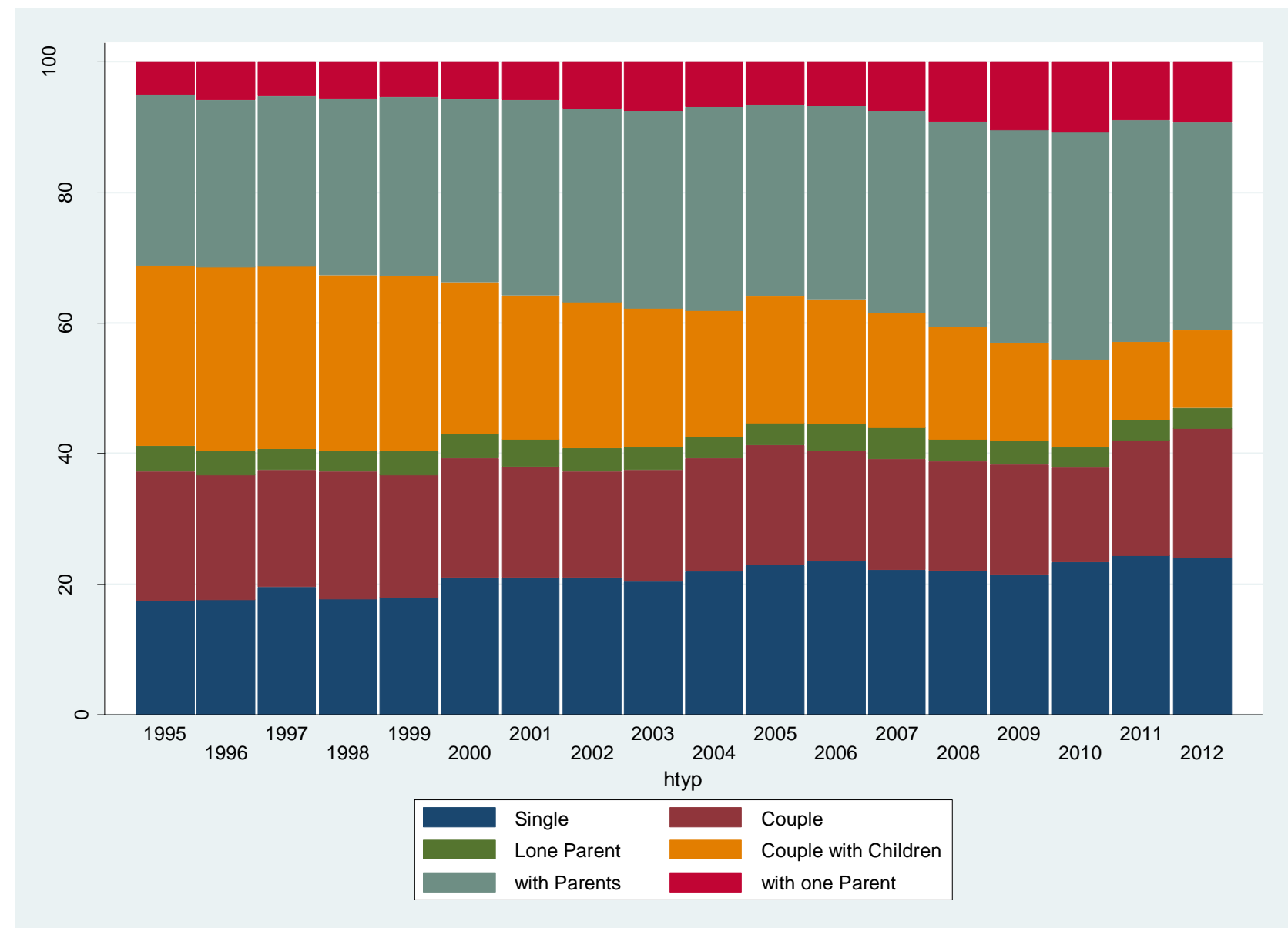

SOEPv29, 1995-2012, weighted results.

The trends in youth transitions can be assumed to interact in complex ways with the increased risk of experiencing poverty during youth and young adulthood. Overall, the transition period to adulthood has become extended, taking young adults much longer than in former periods to acquire good jobs in the labour market and to form their own families. The reasons for this extension of post-adolescence are manifold, including educational expansion and less traditional gender roles for women, and increasing difficulties in the labour market.

These trends might indicate processes of convergence or of polarization between young adults from various educational and social class backgrounds. Has the increasing duration and uncertainty of the transition to adulthood led to a democratization of risks, extending to the middle classes, or are risks concentrated among the offspring of the lower social classes? Answering this question requires empirical examination of the inter-relations of social background, youth transitions, and poverty risks. In this article, we analyze potential precursors and consequences of youth poverty from life course and social class perspectives. We examine the precursors of youth poverty with a particular focus on the "Big Five" transitions to adulthood, i.e., leaving the parental home, cohabitation or marriage, childbirth or becoming a parent, educational completion and labour market entry (Schulenberg \& Schoon, 2012). We ask to what extent these five transitions and poverty risks are inter-related: Do certain transitions lead to poverty or does poverty hinder or foster certain transitions? At the same time, we ask whether the impact of social origins on youth poverty has indeed widened or loosened.

In addressing these questions, we need to account for a particular pitfall in the analysis of poverty among young adults. Many young adults from higher social class backgrounds leave their parental homes for university education and usually live on low incomes during the period of their studies. However, while they appear to live 
independently, they might still receive support from their parents, including monetary transfers, but also in-kind transfers. In this paper, we make use of the unique feature of household panel data to link children who live independently, with the households of their parents, in order to take into account potential inter-generational support. Moreover, we assess the life course consequences of youth poverty in Germany, making use of longterm panel data to trace youth through their transitions to adulthood.

\section{Data and measurement}

We use data from the German Socio-Economic Panel Study (SOEP), which surveys a nationally representative sample of private households annually (Wagner, Frick \& Schupp, 2007). The SOEP started in 1984 in West-Germany and included a sample from Eastern Germany immediately after the fall of the Berlin Wall in 1989. We use data from all supplementary and refreshment samples and all waves through 2012. The SOEP collects personal information from all adults aged 17 years and older in the household. Information on younger children and on the household level are collected from the head of the household. The SOEP data provide a unique opportunity to assess life-course transitions from youth to adulthood, and to account for intergenerational support by linking young adults, who have left their parental homes, with their parents.

Given that there is no commonly accepted definition of youth and any definition of age groups remains arbitrary, we focus on youth and young adults aged 15 to 30 years in order to cover the period of the transition from school to work. This age band is also used in many European youth reports (e.g., the EU Youth Reports from 2009 and 2011 define youth as those aged 15-29, see EU 2009, 2011).

In assessing the impacts of transitions on youth poverty, we control socio-demographic characteristics including gender, age, region (West vs. East Germany), and migrant status $\left(1^{\text {st }}\right.$ and $2^{\text {nd }}$ generations). Social background is based on the higher level of education of both parents and the social class of the father or - if not available - the mother. This information mostly comes from the personal interviews of the parents themselves, or otherwise from the children's biographical questionnaire. The educational attainment of the parents is measured using the CASMIN classification of general and vocational degrees (Projektgruppe
SOEP, 2012: 57f.). ${ }^{2}$ The social class status is determined based on the Goldthorpe class scheme (EGP class scheme, cf. Erikson and Goldthorpe, 1992: 28-64). We use a collapsed six-class version comprising the higher service class (managers, administrators, large employers and academic professionals), the lower service class (highly qualified clerks and civil servants), routine nonmanual and service sales occupations, small selfemployed with less than five employees (including farmers), skilled manual, and unskilled (including farm) manual workers.

The "Big Five" transitions to adulthood are measured separately by five variables indicating whether young adults (1.) still live with their parents, (2.) live with a partner (cohabitation) ${ }^{3}$, (3.) have a child, (4.) educational enrollment, and (5.) labour market status. Educational enrollment is measured as student status in an educational institution (secondary school, vocational training, or university) at the time of the interview. Labour market participation is measured by employment status (gainfully employed, unemployed, inactive/not working) and labour market segment. Among the gainfully employed, labour market segment is indicated by a composite index of the following three dimensions: hourly wages (below two thirds of the median wage of a fulltime employed West-German man, more than $150 \%$ of this wage, or in-between), required qualification (no qualification, vocational training, or tertiary education), and the employment relationship, which distinguishes a standard employment relation (fulltime permanent employment or freelancer), a precarious employment relation (fixed-term, job creation scheme, minor employment, like so-called "mini-/midi-job"), and in-between employment relations (part-time employment with otherwise standard employment relation characteristics, and non-academic solo selfemployed). These three indicators are classified into three labour market segments (high, intermediate, low). Jobs in the high labour market segment usually require at least a vocational degree, provide hourly wages above the median wage, and are permanent fulltime (or self-)employments. Jobs in the lower segment of the labour market are paid below two thirds of the median wage, do not require a vocational qualification, and mostly are precarious in terms of fixed-term employments or employments without social security contributions. 
Jobs in the intermediate sector fall in-between and are mixed in terms of positive and negative characteristics in the three dimensions. ${ }^{4}$

Poverty is measured conventionally as relatively low income, using a threshold of $60 \%$ of the national median income (including East Germany since 1992, the first wave when annual income data was collected in East Germany). We use annual net household income, including an estimate of imputed rent, in order to account for the income advantage arising from home ownership or subsidized rents (Frick \& Grabka, 2003). Thus, this measure accounts for the income advantage of students living in subsidized student housing, or for those reporting no rents at all. Net household income is needs-adjusted according to the new OECD scale (i.e., assigning a weight of 0.5 to every adult in addition to the household head and 0.3 to any child up to age 16). Although annual incomes refer to the calendar year prior to the time of the interview, we reference the year of data collection.

\section{Adjusted poverty measure of potential inter-generational support}

The conventional approach to income poverty assumes that all individuals living in the same household pool and share their economic resources, while separate households are seen as independent economic units. According to this premise, the same child from a wealthy parental home appears to be "wealthy" if still living with parents, but "poor" if living outside the parental home and on low income. This might be misleading because it implicitly assumes that parental support immediately stops when children leave home. Moreover, it ignores the fact that living independently, even if associated with some material losses, is an important step in the transition to adulthood. Independent residence is more prevalent among young adults originating from wealthier families than those from less welloff families, who tend to hinder and postpone this transition due to its high costs (Mayer, Müller \& Pollak, 2007). Leaving the parental home, despite the decline in living standards, often increases life chances by offering young adults opportunities for independence and new experiences. Hence, the standard poverty measure runs the risk of artificially counting young adults as "poor", who in fact are on a life course trajectory from privileged families of origin, to advantageous social positions. This holds particularly true for university students from wealthy families. In many European societies, a period of university studies, marked by low economic resources and poor material living conditions, is a typical stage within upper class lifecourses. Low economic resources and living standards are traditionally assumed to foster the character of the student, who follows the "deferred gratification pattern" of investment in human capital. Although this academic tradition might have weakened over time, it is still apparent in the economic situation of German university students.

In addressing youth poverty, it is important to clarify the underlying concept of poverty. The sociological definition of poverty, developed by Townsend (1979) and further refined by, amongst others, Mack and Lansley (1985) and Nolan and Whelan (1996) and adopted by the EU commission, focuses on exclusion from minimum acceptable living conditions and participation in society, due to a lack of economic resources. It is not the lack of economic resources as such that defines poverty, but the impact that the lack of resources forcefully exerts on living conditions and social participation. This conceptualization has spurred attempts to directly measure living conditions and participation, and to identify exclusion from these due to a lack of economic resources. As emphasized by Mack and Lansley (1985), the notion of poverty refers to the adverse impact of low economic resources on the future life chances of an individual. The standard approach to measuring poverty just serves as an approximation, or indirect measure of this risk. In the case discussed above, this approximation might systematically fail..$^{5}$

The various kinds of inter-generational support that young adults might receive during their education, and during university studies in particular, are typically not well covered in surveys. As a household panel study, the dataset that we use offers a unique opportunity to consider potential inter-generational support, as parents and their children are tracked over time. Thus, we are able to link young adults with the parental homes that they have left. Although we do not know to what extent parents actually support their residentially independent children economically, the data enable a reasonable estimation. ${ }^{6}$ The income data in the SOEP does contain information about incomes from "private transfers from other persons out of the household", which enters the computation of 
household income that we use when measuring adult child poverty. Because there is a separate question for receiving alimony payments, it can be assumed that the private transfers received by independently living young adults are mainly transfers from their parents.

Table 1 provides descriptive statistics on the share of young adults living outside of their parents' home, who report receiving private transfers, and the average amount of these transfers as a percentage of their net equivalized incomes. In addition, we report respective figures for student loans provided by the German Government for trainees or students from low income families (so called "Bafög"). The first column of Table 1 reports the yearly net equivalized income for young adults (aged 15 to 30 years) in Euro (deflated to consumer prices of the year 2000). Individual incomes are almost equal for young adults in education or not working, whereas they are roughly $80 \%$ higher for those working. Almost half of the students do report receiving private transfers from other persons outside the household, but these transfers amount to only $22 \%$ of their net equivalized incomes. For those in vocational training, only $12 \%$ report receiving private transfers, but these make up only $3 \%$ of their overall budgets. Table 1 shows that the private transfers reported by young adults who left their parental homes are rather small. ${ }^{7}$

Table 1. Income, private transfers and student loans of young adults aged 15-30 years and living independently (2005-2012)

\begin{tabular}{lcccccc}
\hline \hline & $\begin{array}{c}\text { equivalized } \\
\text { income } \\
\text { (in Euro as of } \\
\text { 2000) }\end{array}$ & $\begin{array}{c}\text { \% share } \\
\text { receiving } \\
\text { private } \\
\text { transfers }\end{array}$ & $\begin{array}{c}\text { private } \\
\text { transfers as } \\
\text { \% of } \\
\text { equivalized } \\
\text { income }\end{array}$ & $\begin{array}{c}\text { \% share } \\
\text { receiving } \\
\text { student } \\
\text { loan } \\
\text { (Bafög) }\end{array}$ & $\begin{array}{c}\text { student loan } \\
\text { as \% of } \\
\text { equivalized } \\
\text { income }\end{array}$ & N \\
\hline $\begin{array}{l}\text { university } \\
\text { studies }\end{array}$ & 10,519 & $49 \%$ & $22 \%$ & $35 \%$ & $14 \%$ & 2,189 \\
$\begin{array}{l}\text { vocational } \\
\text { training }\end{array}$ & 10,757 & $12 \%$ & $3 \%$ & $23 \%$ & $7 \%$ & 825 \\
$\begin{array}{l}\text { not working } \\
\text { working }\end{array}$ & 11,690 & $3 \%$ & $1 \%$ & $3 \%$ & $1 \%$ & 2,414 \\
\hline Total & 18,293 & $2 \%$ & $0 \%$ & $2 \%$ & $0 \%$ & 7,239 \\
\hline \hline
\end{tabular}

SOEPV29, 2005-2012, weighted results.

However, on top of the regular payments that parents provide to their children and that are reported by the latter as "private transfers", young adults often receive irregular monetary and in-kind support by their parents. What is even more important, wealthy parents serve as a kind of safety net or insurance for their children even if they do not actually use or request economic support. Even if young adults originating from wealthy families do manage to live on restricted incomes while attending universities, they are not at risk of being or becoming socially marginalized or excluded because of inadequate resources. In other words, they are not poor.

To enable us to consider potential intergenerational support, and in the absence of complete information on the degree to which parents share their economic resources with their residentially independent children, we provide a lower-bound estimate of youth poverty based on the extreme assumption of complete income pooling. This "family-adjusted" measure of youth poverty is as much a lower-bound estimate of youth poverty as the "standard measure" of poverty can only provide an upper-bound estimate of youth poverty. We calculate the family-adjusted poverty measure by adding the incomes of parents and children who have moved out of the parental home, and dividing their total combined incomes by the sum of needs of both households (see Table 2 for an example). In other words, we assume income pooling, but we do not alter household needs because there are two independent households. The incomes of young adult children who reside with their parents are computed in the usual manner. 
Table 2. Virtual income pooling of parents and residentially independent children - example

\begin{tabular}{|l|c|l|c|c|}
\cline { 2 - 5 } \multicolumn{1}{l|}{} & income & needs & $\begin{array}{c}\text { equivalized income } \\
\text { - standard measure }\end{array}$ & $\begin{array}{c}\text { equivalized income - } \\
\text { adjusted measure }\end{array}$ \\
\hline Parents (2 adults) & 6300 & $1+0.5=1.5$ & $6300 / 1.5=4200$ & \multirow{2}{*}{$(6300+800) /(1.5+1)=2840$} \\
\hline Child & 800 & 1 & $800 / 1=800$ & \\
\hline
\end{tabular}

This, of course, provides an upper bound estimate of the "true" welfare, since it assumes that parental and offspring incomes are fully shared when they live apart. This assumption most likely overestimates the share of resources that parents make available for their children. Moreover, we thereby also include income flows in the other direction, i.e., we assume that children help out their parents if the parents have fewer resources. In order to avoid double-counting the private transfers that young adults receive from their parents when they are reported by the parents as their own incomes, and again by the child as income, we deduct all "private transfers received from other persons outside the household" reported by the child when calculating the pooled income measure.

This adjustment is, of course, only possible for young adults whose parents still participate in the SOEP survey. Thus, young adults, who have already left the parental home but whose parents did not participate in the SOEP, are excluded from the sample when using the family-adjusted income measure. In cases where more than one parent is available (due to divorce and new partners), we assume income pooling with the mother, or if the mother is not available, with the (first) father.

Table 3 gives an overview - for the recent years
2005 to 2012 - of sample sizes and poverty rates based on the original and the family-adjusted measures, separated by living arrangements and availability of parental information. Very few young adults between the age of 15 and 19 have left the parental home. In the 20-25 year age-group, there are slightly more residentially independent young adults for whom we have parental information in the SOEP $(452+2,305)$ as for those whom we do not $(2,354)$ in the years 2005 to 2012. Between age 26 and age 30, there are many more young adults for whom we do not have parental information $(5,062$, compared to 3,589 for those whom at least one parent can be found in the SOEP). Comparing the unadjusted poverty rates for those young adults for whom we do and do not find parents in the SOEP, we see that those are almost the same ( $20 \%)$ for young adults aged 26 to 30 years, but significantly lower (35\% vs. $50 \%$ ) for those without parents in the SOEP in the age group 20 to 25 years. This difference might be due to the fact that in the younger age group, those for whom we cannot find parents in the SOEP have left their parental home already some years ago and managed to live on their own incomes, as compared to those who left home more recently and for whom we can still find parents in the SOEP.

Table 3. Sample sizes and poverty rates before and after family adjustment (years 2005-2012)

\begin{tabular}{|c|c|c|c|c|c|}
\hline & & 15 to 19 & 20 to 25 & 26 to 30 & Total \\
\hline \multirow[t]{2}{*}{ Living with 1 parent } & $\mathrm{n}$ & 2,347 & 1,875 & 498 & 4,720 \\
\hline & \%poor & $42.0 \%$ & $22.2 \%$ & $12.0 \%$ & $30.3 \%$ \\
\hline \multirow[t]{2}{*}{ Living with 2 parents } & $\mathrm{n}$ & 10,602 & 8,016 & 2,074 & 20,692 \\
\hline & $\%$ poor & $13.7 \%$ & $7.8 \%$ & $7.8 \%$ & $10.9 \%$ \\
\hline \multicolumn{6}{|l|}{ Living independently } \\
\hline \multirow[t]{3}{*}{1 parent in SOEP } & $\mathrm{n}$ & 30 & 452 & 604 & 1,086 \\
\hline & \%poor & $(85.0 \%)$ & $52.8 \%$ & $29.4 \%$ & $41.3 \%$ \\
\hline & \%poor_adj & $(50.3 \%)$ & $38.2 \%$ & $19.1 \%$ & $28.6 \%$ \\
\hline \multirow[t]{3}{*}{2 parents in SOEP } & $\mathrm{n}$ & 91 & 2,305 & 2,985 & 5,381 \\
\hline & \%poor & $(80.3 \%)$ & $50.3 \%$ & $20.5 \%$ & $34.7 \%$ \\
\hline & \%poor_adj & $(35.4 \%)$ & $11.5 \%$ & $5.0 \%$ & $8.4 \%$ \\
\hline \multirow[t]{2}{*}{ No parents in SOEP } & $\mathrm{n}$ & 122 & 2,354 & 5,062 & 7,538 \\
\hline & \%poor & $32.1 \%$ & $34.6 \%$ & $20.3 \%$ & $25.1 \%$ \\
\hline \multirow[t]{2}{*}{ Total } & $\mathrm{n}$ & 13,192 & 15,002 & 11,223 & 39,417 \\
\hline & \%poor & $20.9 \%$ & $24.8 \%$ & $19.6 \%$ & $22.0 \%$ \\
\hline Total (with parents in SOEP) & \%poor_adj & $38.7 \%$ & $17.3 \%$ & $7.8 \%$ & $12.6 \%$ \\
\hline
\end{tabular}

SOEPV29, 2005-2012, weighted results. 
As can be seen from Table 3, the impact of the family adjustment is large. For young adults aged 20 to 25 years for whom we do have information from both parents in the SOEP, the standard poverty rate is $50 \%$, whereas the adjusted poverty rate comes down to almost $11.5 \%$; for young adults aged 26 to 30 years, the family adjustment reduces poverty rates from $20.5 \%$ to $5 \%$. In sum, almost $72 \%$ of the young adults (aged 15 to 30 years) who, based on the standard approach appear to be poor, are rendered non-poor once the available parental income information is taken into account. Again, as these figures demonstrate, this adjustment provides a lower-bound estimate of poverty rates of young adults, thus most likely underestimating true poverty rates. However, it also becomes clear that the standard approach provides an upper-bound estimate that obviously overestimates poverty of young adults who have already left the parental home.

In the following analysis, we report results based on the family-adjusted poverty measure in addition to results obtained from the standard poverty measure. Comparing the results reveals in greater detail, social class differences in the precursors and effects of youth poverty in the course of the transitions to adulthood. Given class-specific differences in the pathways to adulthood, we expect a stronger direct impact of social background on the precursors of youth poverty and a lower impact of the transitions to independent living, family formation and enrollment in tertiary education.

\section{Youth poverty and youth transitions in Germany: trends over time}

In Germany, poverty has risen for more than three decades (Groh-Samberg \& Voges, 2012). After a period of low poverty during the 1960s and 1970s, poverty rates started to increase, fuelled by the stepwise increase of mass unemployment. A particularly large increase has taken place between 2000 and 2005. Figure 3 shows the time trend of (standard) poverty from 1995 to 2012 for the German population separated by age groups.

In West Germany before re-unification, poverty risks were typically U-shaped across age groups, with the highest poverty rates for children and the elderly. Only since the turn of the millennium has a new pattern emerged, with the highest poverty risks in the age group between 20 and 25 years. In recent years, poverty risks of those aged 20-25 years decreased again, remained stable in the younger (15-19 years) and further increased in the older (26-30 years) age group, so that these groups actually converged. For the others, and for the overall population, the trend since 2005 has been almost stable. For the age group of 26 to 30 years, however, the poverty increase during the 2000s was particularly strong. This indicates that the most vulnerable period is probably shifting over the life course towards extended post-adolescence. Whether this might be at least partly due to the Great Recession is difficult to answer from the simple descriptive picture.

However, as discussed above, the substantial increase in poverty among young adults might be a result of a statistical or at least demographic artefact. If more and more young adults leave their parental home for university studies or vocational education, the increase of poverty might simply reflect the growing prevalence and length of the educational phase. Time trends in post-secondary education and leaving the parental home support this conjecture: the age of leaving the parental home is decreasing and the educational enrollment of young adults is increasing over time. We also find a slightly U-shaped pattern of leaving the parental home by socio-economic status: Young adults from poorer as well as from very rich families leave their parental home earlier than those from middle class households. However, no significant change in this pattern can be found over time (cf. also Scherger, 2009; Leopold, Geißler \& Pink, 2011).

Figure 4 shows standard and adjusted poverty rates for the three age groups of 15-19 years, 20-25 years and 26-30 years. As can be seen, this revision clearly reduces the poverty rates of young adults and also eases the upward trend of poverty amongst young adults. Poverty rates remain almost unchanged for those aged 15 to 19 years, as there are only very few youth who have already left the parental home. For those aged 20 to 25 years, poverty rates are almost halved, and for those aged 26 to 30 years, the reduction is even stronger. The poverty risk for these two age groups is now below that of the age group of 15-19 years. However, we still find a significant increase of poverty over time. 
Figure 3. Time trends of poverty in Germany 1995-2012, by age

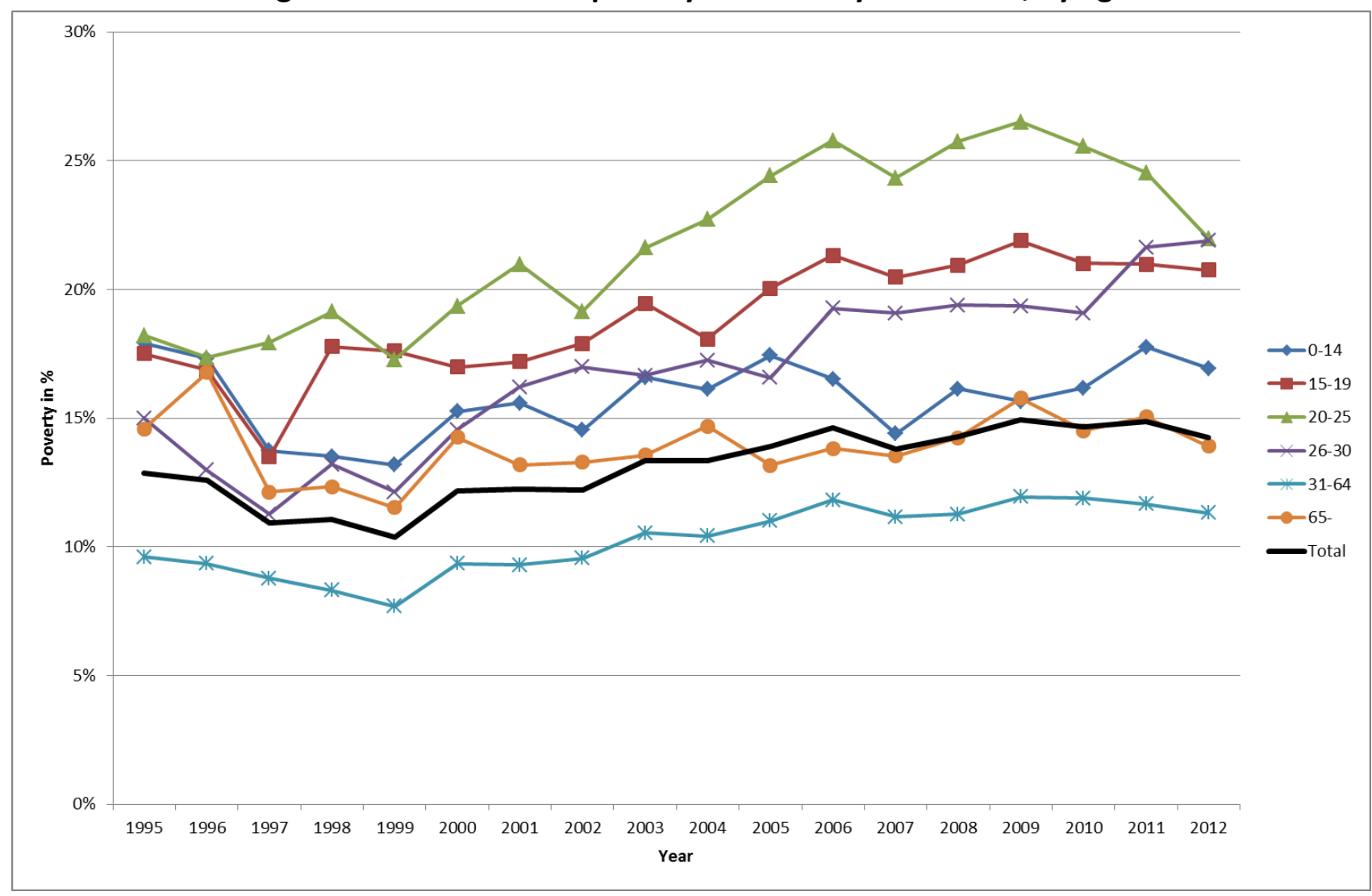

SOEPV29, 1995-2012, weighted results.

Figure 4. Standard vs. family-adjusted poverty rates for young adults (1995-2012)

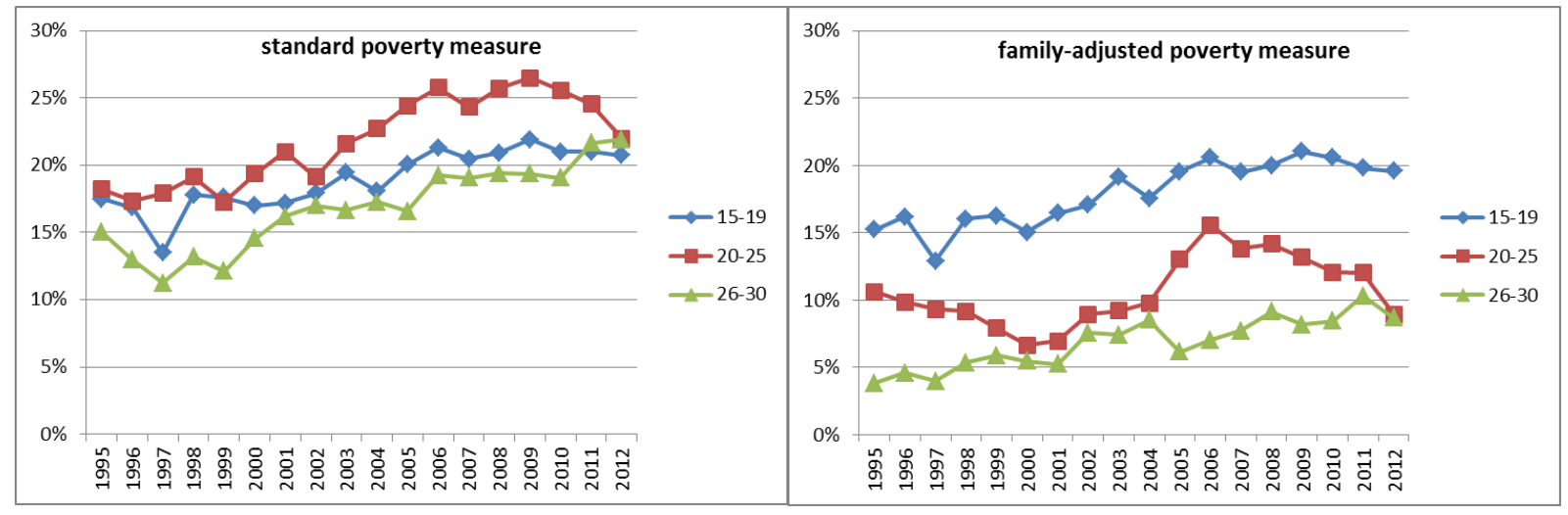

SOEPv29, 1995-2012, weighted results.

\section{Potential precursors of youth poverty}

To what extent is poverty during youth and young adulthood related to the patterns of transition to adulthood and to social class background? And can we observe significant changes in the ways youth poverty was and is affected by these factors? These two questions will be addressed using regression analysis of youth poverty. We start with an analysis of the potential antecedents of youth poverty and, in a second step, look into changes in these antecedents over time. 


\subsection{Potential precursors of youth poverty, 1995-2012}

To analyze the potential precursors of poverty, we estimate a set of regression models based on a sample of youth and young adults aged 15 to 30 in the years from 1995 to 2012 using an unbalanced panel, i.e. of all individuals aged 15 to 30 years with at least one valid observation. The sample consists of more than 15,000 individuals with at least one, at maximum 16 and on average five observations. The first model is a simple pooled linear probability model (LPM), with Huber-White standard errors to account for heteroscedasticity and for the fact that observations are nested in persons. Second, we estimate a fixed effects panel regression (FE model). This model uses within-person variance to estimate the effect of independent variables net of unobserved individual heterogeneity. These effects can be interpreted as causal if the assumption holds that there are no unobserved time-varying factors correlated with any of the independent variables (Mood, 2010; see also Ermisch \& Francesconi, 2001). However, the fixed effects model excludes all individuals who never experienced a change in poverty status, and it does not allow time-constant independent variables. Thus, this model is not well designed to capture causal effects that operate as constant social forces, e.g. in terms of "structuration" (Giddens, 1984). In order to retain time-constant factors and individuals with stable states, we thirdly estimate a hybrid panel regression model (HYBRID). This model is a random effects panel regression in which time-variant independent variables are split into a time-constant mean (capturing between-persons differences) and a time-dependent deviation from the mean (capturing the within-person variance that can be interpreted like that in a fixed effects model).

Although poverty is a binary response variable, and thus should be analyzed using logistic regressions, we present LPMs following the approach suggested by Mood (2010). The interpretation and comparison of LPM coefficients across models is more straightforward than for coefficients in logit models. ${ }^{8}$ Thus, the coefficient of 0.103 for first generation migrants (Table 4, Column 1) can be interpreted as a 10.3 percentage points higher poverty rate for first generation migrants as compared to native Germans, everything else being equal. However, as Mood (2010) notes, this interpretation should be treated with caution, given that the magnitude of the coefficient depends on the baseline poverty rate for the respective reference group.

A comparison across these three models provides a comprehensive approach to analyzing potential precursors of poverty. By comparing the coefficients across model types, we can first assess how robust the results are. Moreover, comparing the between-persons and the within-persons effects, we get a grip on the potential causal direction: do youth transitions (e.g., entering university studies or becoming a parent) cause poverty, or does poverty render certain transitions more or less likely? Whereas the simple crosssectional model shows the overall strength of the correlations between covariates and poverty, the fixed effects model reveals to what extent certain transitions impact on the risk of becoming or staying in poverty, as opposed to the selection of the poor into certain youth transitions.

We start with the results based on the standard poverty measure (left panel of Table 4). The results show that women and West Germans have a slightly lower poverty risk than men and East Germans, and migrants, in particular first generation migrants, have higher probabilities of being poor. Social background has a very strong impact, both in terms of parental education and (father's) social class. Although parental education and father's social class are highly correlated, we find strong significant effects for both measures of social background. Poverty risks for youth originating from unskilled worker households are about 8 percentage points higher than for youth originating from higher service class households; and the difference between low-skilled versus university education backgrounds is 14 percentage points.

Turning to the youth transitions, we find strong effects as well. Leaving the parental home has a huge positive impact on poverty, both between and within persons. When leaving the parental home, poverty risks increase by more than 40 percentage points. This confirms that young adults who left their parental home, live on lower economic resources than those who still live in the parental household. On the other hand, cohabitation has a protective effect, again both between and within persons. Thus, when young adults leave the parental home to immediately form a couple household, both effects seem to be countervailing 
Table 4. Determinants of youth poverty

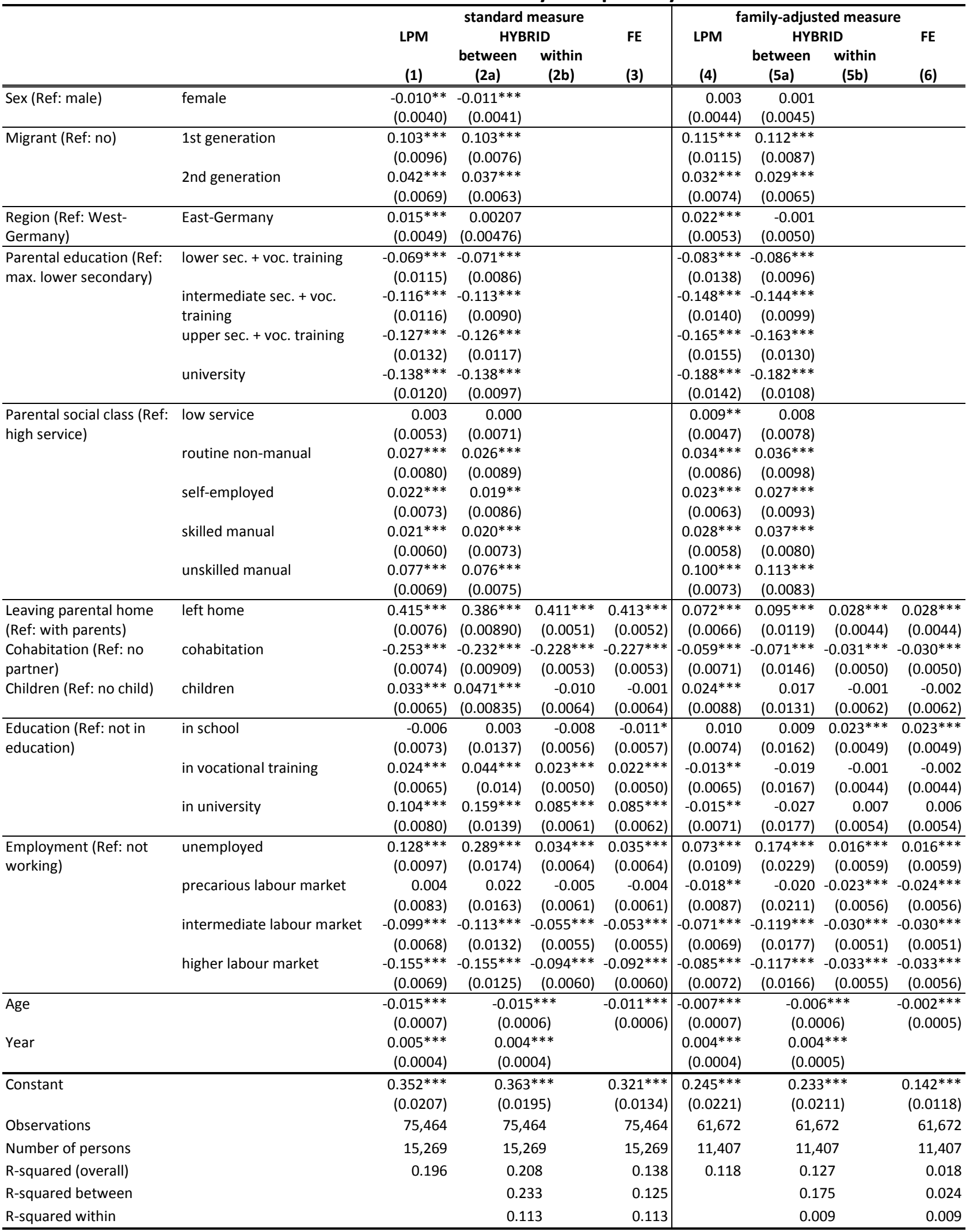

Source: SOEPV29, 1995-2012, own calculation. Robust standard errors in parentheses. ${ }^{* * *} p<0.01,{ }^{* *} p<0.05,{ }^{*} p<0.1$. 
or to at least partially reduce one another. Interestingly, parenthood has no clear effect. Although having children is associated with higher poverty risks according to the simple LPM model and the between-effect of the HYPBRID model (Columns 1 and 2a), there is no such effect in the fixed effects part of the HYBRID model and the FE model (Columns $2 b$ and 3 ). In other words, it is not the newborn baby that causes poverty for young families. Rather, poor young adults have a higher probability of having a child. This result corresponds to research findings showing that unemployment can serve as a trigger for childbirth for poorly educated women (Düntgen \& Diewald, 2007).

Educational enrollment and labour market participation exert strong and consistent effects as well. Taking up vocational training and university studies clearly increases the likelihood of poverty when measured conventionally. With an increase of 8 percentage points, this effect is more pronounced for taking up university education than for vocational training ( 2 percentage points). This supports our expectation that university studies serve as a status passage which is coupled with low living standards. Regarding labour market participation, being unemployed has a huge impact on poverty when compared to persons who are not unemployed. The effect is still there, but strongly reduced in the fixed effects perspective, indicating that poverty does not only follow unemployment but also often precedes unemployment. On the other hand, a consistent protective effect against poverty can be found for taking up a job in the higher or intermediate labour market segments. The effects for precarious jobs are not statistically different from not working.

We have estimated two complete sets of regression models based on the standard and on the family-adjusted poverty measure. ${ }^{9}$ We expect that the results based on the adjusted measure will boost the effects of social origin and at least partially downsize those for the five youth transitions, in particular leaving the parental home and taking up university studies. These expectations are largely confirmed. We find the effects of parental education and social class to be much stronger based on the family-adjusted poverty measure. In contrast, the effects of youth transitions are downsized or even disappear. The huge poverty enhancing impact of leaving the parental home and the protective effect of cohabitation are strongly reduced from around 40 to only 3 percentage points in the fixed effects model. These results clearly indicate that students enrolled at universities overwhelmingly originate from wealthier parental backgrounds (see Mayer, Müller \& Pollak, 2007), and follow the "deferred gratification pattern" during the investment period in human capital. The positive effects for entering vocational training or university studies almost disappear. There is even a reverse protective effect for being in vocational training or university in the LPM model (Column 4); however, this does not hold for the within-person variance. Thus, participation in post-secondary and tertiary education itself has no poverty enhancing or reducing effect once potential inter-generational support is accounted for. What remain unchanged are the negative effects of unemployment and the protective effects of employment. Even precarious employment in the lower labour market shows a consistent, albeit small protective effect against poverty in a longitudinal perspective. Again, although youth poverty is strongly correlated with having children, in a longitudinal perspective the transition to parenthood exerts much less impact on poverty than could have been expected from the simple correlations.

Finally, all models in Table 4 include age as a continuous variable. The consistently negative and significant coefficient for age in all models indicates an endogenous trend of "growing out of poverty" with age. Given the n-shaped age-pattern of poverty, we checked for non-linear age effects by including age squared, but omitted this variable because it was not significant. Once controlling for the transitions to adulthood, like leaving home, attending education and entering the labour market, we find evidence that young adults might follow an endogenous developmental path out of the risk zone of poverty. Second, we find a significant positive effect of time in the LPM models (given that change in age and change in time are perfectly collinear, they cannot be disentangled in the FE models). This indicates that the increase in poverty of youth and young adults cannot simply be reduced to compositional changes (at least with respect to the characteristics included in our models). Even after controlling for social background and the "big five" youth transitions, the transition to adulthood has become more risky over time in Germany. However, the models presented 
so far assume that there are no changes in the precursors of poverty over the period of study - this needs further elaboration.

\subsection{Changes over time}

The long-term increase of youth poverty has not accelerated during the recent economic crisis in Germany. On the contrary, poverty rates have declined at least for young adults aged 20 to 25 and this decline is even steeper for the familyadjusted poverty measure (see above, Figure 4). The question then is: How can we explain these trends? Did the correlates of poverty change during the steep increase of youth poverty between 2000 and 2005 and the period before and after? Has the recent recession affected the determinants of youth poverty? In order to address these questions, and to account for potential non-linear time changes, we analyze youth poverty for three time periods with differing poverty trends: The first period is 1995 to 2000, when youth poverty rates for those aged 15 to 30 years were almost stable at a level of about $16 \%$. During the second period from 2001 to 2006 , poverty rates sharply increased from $16 \%$ to $22 \%$, and remained at this high level for most of the third period between 2007 and 2012. We only report LPM models to search for robust changes in the correlates of youth poverty. As before, we estimate the regressions based on the standard and adjusted poverty measures. Results are given in Table 5.

Resembling the results from the previous regressions, we find only very weak effects for gender and region, but strong effects for migrants, in particular first generation migrants, and social background. In fact, the impact of social background is increasing over time. This increase is even stronger for the family-adjusted poverty measure than for the conventional approach. This is true for parental education as well as for class background. This pattern indicates the growing significance of social inequality for the stratification of youth poverty risk. On the other hand, youth transitions again strongly affect poverty risk, but these effects are rather stable over time, and they are again less pronounced for the family-adjusted poverty measure. Whereas university studies are increasingly correlated with poverty, based on the standard poverty measure, there is no significant correlation between university studies and the family-adjusted measure of poverty. For vocational training, the increasing correlation with the standard poverty measure even turns into a significantly negative correlation for the familyadjusted measure of poverty. The only increasing correlation that remains in place when poverty is corrected for inter-generational support is for unemployment. For precarious jobs in the lower segment of the labour market, we only find significant effects in the last time period, which are positive for the standard poverty measure but negative for the family-adjusted poverty measure.

To summarize, the regression models for the three time periods reveal that the risks of poverty during the transition to adulthood are becoming increasingly determined by social stratification. This is reflected in the increasing impact of social origin, whereas the impacts of youth transitions remain rather stable over time. However, this trend seems to be rather continuous instead of jumpy or sudden. This is, of course, what we would expect when considering social class effects. Rising youth poverty in Germany seems to be an outcome of structural changes in social stratification, changes that appear to operate rather slowly, but "in the depth" of social reality. 
Table 5. Period change in the correlates of youth poverty

\begin{tabular}{|c|c|c|c|c|c|c|c|}
\hline & \multicolumn{3}{|c|}{ standard measure } & \multicolumn{3}{|c|}{ family-adjusted measure } \\
\hline & & $1995-2000$ & 2001-2006 & 2007-2012 & 1995-2000 & $2001-2006$ & 2007-2012 \\
\hline \multirow[t]{2}{*}{ Sex (Ref: male) } & female & $-0.012^{* *}$ & $\begin{array}{l}-0.003 \\
0.0057\end{array}$ & $\begin{array}{r}-0.016^{* *} \\
(0.064)\end{array}$ & & $\begin{array}{c}0.003 \\
(0.0059)\end{array}$ & $\begin{array}{c}0.007 \\
(0.0065)\end{array}$ \\
\hline & & $\begin{array}{l}(0.0061) \\
0.115 * *\end{array}$ & $(0.0057)$ & $\begin{array}{l}(0.0064) \\
0.074 * * *\end{array}$ & $(0.0065)$ & $(0.0059)$ & $\begin{array}{l}(0.0065) \\
0.100 * * *\end{array}$ \\
\hline \multirow{3}{*}{ Migrant (Ref: no) } & Ist generation & $(0.0136)$ & $(0.0140)$ & $(0.0160)$ & $(0.0147)$ & $(0.0166)$ & $(0.0192)$ \\
\hline & 2nd generation & $0.050 * * *$ & $0.027^{* * *}$ & $0.048 * * *$ & $0.037 * * *$ & $0.019 *$ & $0.039 * * *$ \\
\hline & & $(0.0106)$ & $(0.0103)$ & $(0.0108)$ & $(0.0106)$ & $(0.0104)$ & $(0.0108)$ \\
\hline \multirow{10}{*}{$\begin{array}{l}\text { Region (Ref: West- } \\
\text { Germany) } \\
\text { Parental education (Ref: } \\
\text { max. lower secondary) }\end{array}$} & East-Germany & 0.005 & $0.017^{* *}$ & $0.013^{*}$ & 0.000 & $0.023 * * *$ & $0.034 * * *$ \\
\hline & & $(0.0070)$ & $(0.0069)$ & $(0.0081)$ & $(0.0072)$ & $(0.0069)$ & $(0.0082)$ \\
\hline & lower sec. + voc. training & $-0.057^{* * *}$ & $-0.059 * * *$ & $-0.127 * * *$ & $-0.065^{* * *}$ & $-0.082 * * *$ & $-0.162 * * *$ \\
\hline & & $(0.0137)$ & $(0.0175)$ & $(0.0258)$ & $(0.0151)$ & $(0.0211)$ & $(0.0300)$ \\
\hline & intermed.sec.+voc.training & $-0.071 * * *$ & $-0.109 * * *$ & $-0.203 * * *$ & $-0.083 * * *$ & $-0.153 * * *$ & $-0.262 * * *$ \\
\hline & & $(0.0148)$ & $(0.0174)$ & $(0.0253)$ & $(0.0166)$ & $(0.0208)$ & (0.0294) \\
\hline & upper sec. + voc. training & $-0.097 * * *$ & $-0.123 * * *$ & $-0.196 * * *$ & $-0.117 * * *$ & $-0.161 * * *$ & $-0.267 * * *$ \\
\hline & & $(0.0183)$ & $(0.0197)$ & $(0.0268)$ & $(0.0189)$ & $(0.0232)$ & $(0.0308)$ \\
\hline & University & $-0.113 * * *$ & $-0.126 * * *$ & $-0.212 * * *$ & $-0.137 * * *$ & $-0.185 * * *$ & $-0.292^{* * *}$ \\
\hline & & $(0.0151)$ & $(0.0179)$ & $(0.0258)$ & $(0.0165)$ & $(0.0211)$ & $(0.0297)$ \\
\hline \multirow{10}{*}{$\begin{array}{l}\text { Parental social class } \\
\text { (Ref: high service) }\end{array}$} & low service & $-0.020 * *$ & 0.007 & 0.012 & 0.000 & 0.009 & $0.017^{* *}$ \\
\hline & & $(0.0083)$ & $(0.0076)$ & $(0.0084)$ & $(0.0063)$ & $(0.0062)$ & $(0.0071)$ \\
\hline & routine non-manual & 0.007 & $0.036 * * *$ & $0.029 * *$ & $0.026^{* *}$ & $0.042 * * *$ & $0.029 * * *$ \\
\hline & & (0.0121) & $(0.0118)$ & $(0.0117)$ & $(0.01$ & $(0.0118)$ & $(0.0108)$ \\
\hline & self-employed & 0.013 & 0.014 & $0.036 * * *$ & $0.029^{* *}$ & $0.013^{*}$ & $0.029 * * *$ \\
\hline & & $(0.0122)$ & $(0.0098)$ & $(0.0115)$ & $(0.0114)$ & $(0.0076)$ & $(0.0103)$ \\
\hline & skilled manual & -0.005 & $0.026^{* * *}$ & $0.037 * * *$ & 0.013 & $0.026 * * *$ & $0.043^{* * *}$ \\
\hline & & $(0.0090)$ & $(0.0086)$ & $(0.0100)$ & $(0.0078)$ & $(0.0076)$ & $(0.0097)$ \\
\hline & unskilled manual & $0.050 * * *$ & $0.084^{* * *}$ & $0.087^{* * *}$ & $0.086^{* * *}$ & $0.099 * * *$ & $0.106^{* * *}$ \\
\hline & & $(0.0101)$ & $(0.0098)$ & $(0.0115)$ & $(0.0096)$ & $(0.0095)$ & $(0.0121)$ \\
\hline \multirow{2}{*}{$\begin{array}{l}\text { Leaving parental home } \\
\text { (Ref: with parents) }\end{array}$} & leaving home & $0.324 * * *$ & $0.438 * * *$ & $0.462 * * *$ & $0.058^{* * *}$ & $0.078^{* * *}$ & $0.072 * * *$ \\
\hline & & $(0.0128)$ & $(0.0115)$ & $(0.0113)$ & $(0.0106)$ & $(0.0096)$ & (0.0099) \\
\hline \multirow{2}{*}{$\begin{array}{l}\text { Cohabitation (Ref: no } \\
\text { partner) }\end{array}$} & cohabitation & $-0.198 * * *$ & $-0.276 * * *$ & $-0.260 * * *$ & $-0.049 * * *$ & $-0.069 * * *$ & $-0.056 * * *$ \\
\hline & & $(0.0122)$ & $(0.0115)$ & $(0.0116)$ & $(0.0110)$ & (0.0099) & $(0.0116)$ \\
\hline \multirow[t]{2}{*}{ Children (Ref: no child) } & children & $0.034 * * *$ & $0.024^{* *}$ & $0.047 * * *$ & 0.005 & $0.028^{* *}$ & $0.031^{*}$ \\
\hline & & $(0.0088)$ & $(0.0104)$ & $(0.0124)$ & $(0.0100)$ & $(0.0126)$ & $(0.0178)$ \\
\hline \multirow{6}{*}{$\begin{array}{l}\text { Education (Ref: not in } \\
\text { education) }\end{array}$} & in school & 0.013 & -0.013 & 0.022 & 0.010 & $-0.031 * *$ & -0.009 \\
\hline & & $(0.0156)$ & $(0.0124)$ & $(0.0145)$ & $(0.0154)$ & $(0.0123)$ & $(0.0143)$ \\
\hline & in vocational training & 0.004 & $0.031 * * *$ & $0.034 * * *$ & $-0.021^{*}$ & -0.011 & $-0.020^{*}$ \\
\hline & & $(0.0118)$ & $(0.0100)$ & $(0.0113)$ & $(0.0118)$ & $(0.0097)$ & $(0.0112)$ \\
\hline & in university & $0.073^{* * *}$ & $0.102^{* * *}$ & $0.118^{* * *}$ & -0.013 & 0.002 & -0.018 \\
\hline & & $(0.0146)$ & $(0.0123)$ & & $(0.0131)$ & $(0.0104)$ & $(0.0125)$ \\
\hline \multirow{8}{*}{$\begin{array}{l}\text { Employment (Ref: not } \\
\text { working) }\end{array}$} & unemployed & $0.061 * * *$ & $0.109 * * *$ & $0.205^{* * *}$ & 0.018 & $0.069 * * *$ & $0.129 * * *$ \\
\hline & & $(0.0165)$ & $(0.0142)$ & $(0.0175)$ & $(0.0161)$ & $(0.0152)$ & $(0.0207)$ \\
\hline & precarious employment & -0.006 & -0.019 & $0.027^{*}$ & -0.015 & -0.012 & $-0.024^{*}$ \\
\hline & & $(0.0148)$ & $(0.0128)$ & $(0.0141)$ & $(0.0156)$ & (0.0129) & $(0.0140)$ \\
\hline & intermediate segment & $-0.103 * * *$ & $-0.107 * * *$ & $-0.087 * * *$ & $-0.071 * * *$ & $-0.063 * * *$ & $-0.075^{* * *}$ \\
\hline & & $(0.0110)$ & $(0.0103)$ & $(0.0125)$ & (0.0115) & $(0.00978)$ & $(0.0127)$ \\
\hline & higher labour market seg. & $-0.137 * * *$ & $-0.161 * * *$ & $-0.173 * * *$ & $-0.090 * * *$ & $-0.073 * * *$ & $-0.094 * * *$ \\
\hline & & $(0.0108)$ & $(0.0105)$ & $(0.0126)$ & $(0.0114)$ & $(0.0103)$ & $(0.0129)$ \\
\hline \multicolumn{2}{|l|}{ Age } & ok & ok & ok & ok & ok & ok \\
\hline \multicolumn{2}{|l|}{ Year } & ok & ok & ok & ok & ok & ok \\
\hline \multirow{2}{*}{\multicolumn{2}{|c|}{ Constant }} & $0.175^{* * *}$ & $0.243 * * *$ & $0.278^{* * *}$ & $0.177^{* * *}$ & $0.298 * * *$ & $0.344^{* * *}$ \\
\hline & & $(0.0245)$ & $(0.0243)$ & $(0.0312)$ & $(0.0244)$ & $(0.0264)$ & $(0.0345)$ \\
\hline \multicolumn{2}{|l|}{ Observations } & 22,531 & 29,026 & 23,907 & 18,055 & 23,884 & 19,733 \\
\hline \multicolumn{2}{|l|}{ R-squared } & 0.149 & 0.202 & 0.236 & 0.111 & 0.123 & 0.143 \\
\hline
\end{tabular}

SOEPV29, 1995-2012. Robust standard errors in parentheses. ${ }^{* * *} p<0.01,{ }^{* *} p<0.05,{ }^{*} p<0.1$ 
Resembling the results from the previous regressions, we find only very weak effects for gender and region, but strong effects for migrants, in particular first generation migrants, and social background. In fact, the impact of social background is increasing over time. This increase is even stronger for the family-adjusted poverty measure than for the conventional approach. This is true for parental education as well as for class background. This pattern indicates the growing significance of social inequality for the stratification of youth poverty risk. On the other hand, youth transitions again strongly affect poverty risk, but these effects are rather stable over time, and they are again less pronounced for the family-adjusted poverty measure. Whereas university studies are increasingly correlated with poverty, based on the standard poverty measure, there is no significant correlation between university studies and the family-adjusted measure of poverty. For vocational training, the increasing correlation with the standard poverty measure even turns into a significantly negative correlation for the familyadjusted measure of poverty. The only increasing correlation that remains in place when poverty is corrected for inter-generational support is for unemployment. For precarious jobs in the lower segment of the labour market, we only find significant effects in the last time period, which are positive for the standard poverty measure but negative for the family-adjusted poverty measure.

To summarize, the regression models for the three time periods reveal that the risks of poverty during the transition to adulthood are becoming increasingly determined by social stratification. This is reflected in the increasing impact of social origin, whereas the impacts of youth transitions remain rather stable over time. However, this trend seems to be rather continuous instead of jumpy or sudden. This is, of course, what we would expect when considering social class effects. Rising youth poverty in Germany seems to be an outcome of structural changes in social stratification, changes that appear to operate rather slowly, but "in the depth" of social reality.

\section{Long-term consequences of youth poverty for adult poverty}

We now switch the perspective from precursors to outcomes of youth poverty. If the transition to adulthood in Germany has become more risky and uncertain, and youth poverty increased significantly due to rising inequalities, we now assess the impact of youth poverty on poverty risks in later life. To analyze life-course effects of poverty during youth and young adulthood, we construct balanced panels of ten years for various age brackets. The first panel runs from ages 10 to 20 , the second panel from ages 14 to 24 , the third from ages 18 to 28 , and the fourth from ages 22 to age 32 . The dependent variable is an extended poverty measure at the last year of these panels. To give a more valid measure of poverty, the dependent variable only equals one if the individual is in poverty (as gauged by the standard measure), is not enrolled at a university and is not employed in the higher labour market segment. ${ }^{10}$ The independent variable of interest counts the years in poverty during the first five years of the respective ten year period. Thus, the first panel estimates the probability of being poor at age 20 conditional on the years spent in poverty between age 10 and age 14; the last panel, accordingly, estimates the probability of being poor at age 32 dependent on the years spent in poverty during ages 22 to 26. Moreover, we control for gender, migration, region, parental education, and time period.

Table 6 shows that years spent in poverty during the first five years of each ten-year period have the expected strong effect on poverty at the 10th year. These effects appear to operate in all four age ranges. However, comparing the coefficients across age ranges reveals that the life-course effects of poverty are more pronounced in earlier stages of the life-course. Experiencing three to five years of poverty between ages 10 to 15 leads to an increased risk of being poor at age 20 of almost 28 percentage points. This effect decreases to 23,17 and 19 percentage points if evaluated between ages 14 to 24,18 to 28 , and 22 to 32 , respectively. The impacts of temporary poverty experiences of one to two years on later life poverty, decrease even more from 15 percentage points to 5-8 percentage points for all later age ranges. This pattern indicates that the "state-dependency" of poverty weakens during the phase of transition to independent living.

Social background, measured by parental education, also shows a strong impact. Comparing the impact of social background across the four age ranges, we again find a slightly u-shaped pattern: The effect slightly decreases over the first three age 
bands, but then clearly catches-up again with the first age range. This pattern seems to contradict or at least extend the life course hypothesis developed by Blossfeld and Shavit (1993). The transition phase to independent living seems to shake-up or loosen the impact of social origin only slightly, but returns to its full power once the transition phase has come to an end - at least insofar as poverty risks are concerned.

Furthermore, women and East Germans have higher probabilities of being poor at the end of the ten year period after controlling for previous childhood or youth poverty. For migrants, there is an effect only for the two later life-course periods. Although women are, if at all, slightly less likely to become poor during the transition to adulthood (see Table 4, above), those who do have less often experienced poverty spells during (late) childhood.

Finally, the dummy for time periods shows a significant increase in poverty for the most recent period from 2009 to 2012, at least for the first three age groups. The fact that there is no significant increase for the fourth age range (from age 22 to age 32) might indicate that at age 22 to 26 , youth might have already passed by the most troublesome and vulnerable ages that have been hit most by the recent labour market trends. Further testing for increasing effects of parental education or years spent in poverty over time did not show any significant results.

Table 6. Life course effects of youth poverty on poverty risks in later life

\begin{tabular}{|c|c|c|c|c|c|}
\hline & & $10-20$ & $14-24$ & $18-28$ & $22-32$ \\
\hline \multirow[t]{2}{*}{ Years in poverty (Ref: none) } & $1-2$ years & $\begin{array}{c}0.151^{* * *} \\
(0.0186)\end{array}$ & $\begin{array}{c}0.0531^{* * *} \\
(0.0165)\end{array}$ & $\begin{array}{c}0.0789 * * * \\
(0.0148)\end{array}$ & $\begin{array}{c}0.0636 * * * \\
(0.0137)\end{array}$ \\
\hline & $3-5$ years & $\begin{array}{c}0.284^{* * *} \\
(0.0197)\end{array}$ & $\begin{array}{c}0.229 * * * \\
(0.0168)\end{array}$ & $\begin{array}{c}0.168 * * * \\
(0.0181)\end{array}$ & $\begin{array}{c}0.185^{* * *} \\
(0.0171)\end{array}$ \\
\hline Sex (Ref: male) & female & $\begin{array}{c}0.032 * * * \\
(0.0122)\end{array}$ & $\begin{array}{l}0.027^{* *} \\
(0.0110)\end{array}$ & $\begin{array}{c}0.016 \\
(0.0115)\end{array}$ & $\begin{array}{l}0.027^{* *} \\
(0.0106)\end{array}$ \\
\hline Region (Ref: West Germany) & East Germany & $\begin{array}{c}0.034^{*} \\
(0.0176)\end{array}$ & $\begin{array}{c}0.046^{* * *} \\
(0.0161)\end{array}$ & $\begin{array}{c}0.063 * * * \\
(0.0177)\end{array}$ & $\begin{array}{l}0.040 * * \\
(0.0163)\end{array}$ \\
\hline Migration (Ref: no) & migrant & $\begin{array}{c}-0.007 \\
(0.0155)\end{array}$ & $\begin{array}{c}-0.004 \\
(0.0139)\end{array}$ & $\begin{array}{c}0.025^{*} \\
(0.0145)\end{array}$ & $\begin{array}{l}0.030^{* *} \\
(0.0137)\end{array}$ \\
\hline \multirow[t]{3}{*}{ Parental education (Ref: elementary) } & lower secondary & $\begin{array}{c}-0.033 \\
(0.0228)\end{array}$ & $\begin{array}{c}-0.005 \\
(0.0197)\end{array}$ & $\begin{array}{c}-0.016 \\
(0.0191)\end{array}$ & $\begin{array}{c}-0.054 * * * \\
(0.0167)\end{array}$ \\
\hline & upper secondary & $\begin{array}{c}-0.087 * * * \\
(0.0234)\end{array}$ & $\begin{array}{l}-0.048 * * \\
(0.0208)\end{array}$ & $\begin{array}{l}-0.038^{*} \\
(0.0203)\end{array}$ & $\begin{array}{c}-0.082 * * * \\
(0.0183)\end{array}$ \\
\hline & tertiary & $\begin{array}{c}-0.107^{* * *} \\
(0.0254)\end{array}$ & $\begin{array}{c}-0.079 * * * \\
(0.0230)\end{array}$ & $\begin{array}{c}-0.087^{* * *} \\
(0.0225)\end{array}$ & $\begin{array}{c}-0.120 * * * \\
(0.0202)\end{array}$ \\
\hline \multirow[t]{4}{*}{ Time period (Ref: 1993-96) } & $1997-2000$ & $\begin{array}{c}0.005 \\
(0.0226)\end{array}$ & $\begin{array}{c}0.033^{*} \\
(0.0187)\end{array}$ & $\begin{array}{c}0.014 \\
(0.0174)\end{array}$ & $\begin{array}{r}-0.035 * * \\
(0.0169)\end{array}$ \\
\hline & 2001-04 & $\begin{array}{c}0.020 \\
(0.0218)\end{array}$ & $\begin{array}{l}0.043 * * \\
(0.0185)\end{array}$ & $\begin{array}{c}0.003 \\
(0.0189)\end{array}$ & $\begin{array}{c}-0.009 \\
(0.0172)\end{array}$ \\
\hline & 2005-08 & $\begin{array}{c}0.031 \\
(0.0215)\end{array}$ & $\begin{array}{c}0.085^{* * *} \\
(0.0185)\end{array}$ & $\begin{array}{c}0.025 \\
(0.0190)\end{array}$ & $\begin{array}{c}-0.009 \\
(0.0186)\end{array}$ \\
\hline & 2009-12 & $\begin{array}{l}0.048^{* *} \\
(0.0214)\end{array}$ & $\begin{array}{c}0.060 * * * \\
(0.0177)\end{array}$ & $\begin{array}{c}0.051 * * * \\
(0.0185)\end{array}$ & $\begin{array}{c}-0.007 \\
(0.0184)\end{array}$ \\
\hline Constant & & $\begin{array}{c}0.023 \\
(0.0375) \\
\end{array}$ & $\begin{array}{c}-0.063^{*} \\
(0.0326) \\
\end{array}$ & $\begin{array}{c}-0.050 \\
(0.0326) \\
\end{array}$ & $\begin{array}{c}0.017 \\
(0.0300) \\
\end{array}$ \\
\hline Observations & & 2,525 & 2,226 & 2,012 & 2,130 \\
\hline R-squared & & 0.126 & 0.116 & 0.083 & 0.091 \\
\hline
\end{tabular}

SOEPV29, 1984-2012, balanced 10-years panels. Robust standard errors in parentheses.

*** $p<0.01,{ }^{* *} p<0.05, * p<0.1$ 
Summing up, we find strong and persistent effects of youth poverty on poverty risks in the later life-course. This effect is manifest across ten years and when controlling for socio-demographic characteristics. In particular, we find that both earlier poverty experiences during youth and parental background have independent and strong effects on poverty in later life. We also checked for interactions between parental education and earlier poverty experiences, but those were not significant. In other words, poverty experiences during childhood and youth have the same detrimental impact on later life poverty risks in all educational groups or social classes. In line with the findings of the previous sections, we find that poverty risks increased over time even when controlling for earlier poverty experiences.

Interestingly, these results, based on the standard poverty measure, are almost the same for the family-adjusted poverty measure. This indicates that poverty experiences during youth transitions have a consistent detrimental impact. Even children from wealthier backgrounds have higher risks of later-life poverty, compared to their peers who have not experienced poverty during the transition to adulthood.

\section{Conclusion}

In Germany, poverty has been increasing for almost three decades, with a particularly strong acceleration of this increase between 1999 and 2005. A major consequence and driver of this increase is the "solidification" of poverty; poverty has become increasingly persistent for growing parts of the population (see Groh-Samberg, 2013). These trends are seemingly unrelated to the recent Great Recession. The steepest increase in poverty took place years before the onset of the economic crisis of 2008, and there has been no further rise in poverty since the crisis began (Grabka, Goebel \& Schupp, 2012). This provides a puzzle for comparative cross-national analysis of the impact of the economic crisis and uncertainty of youth transitions. Although we cannot contribute to solving this puzzle, the results presented in this paper clearly show that youth transitions have become increasingly risky and difficult in Germany to an extent that might very well be comparable to other countries that have been more deeply hit by the Great Recession.

We find that poverty increased significantly in Germany, even if we take into account intergenerational support by means of virtual income pooling of parents and their residentially independent children. Poverty risks are differently related to the "big five" transitions to adulthood. Leaving the parental home and entering unemployment strongly increase poverty risks, whereas cohabitation and employment in the higher labour market segments are strong protectors against poverty. The transition to parenthood, educational participation and precarious employment are not consistently related to poverty risks once we control for intergenerational support. However, whereas the impact of these transitions does not change over time, we find that social background has a strong and increasing impact on poverty risks. Moreover, we also find that social background and poverty experiences during youth, strongly affect poverty risks later in life. This life-course effect seems to weaken throughout the period of youth transitions. Overall, these results clearly point towards an increasingly persistent inter-generational transmission of poverty and life course risks.

\section{Acknowledgements}

We are very grateful to Jeylan Mortimer for her careful and critical reading of the text and for her helpful comments. We also like to thank three anonymous reviewers for their helpful comments, as well as Ingrid Schoon, John Bynner and the participants of the network "Youth in the Great Recession" for suggestions on earlier versions of this paper. This research has been partially supported by EU-FET grant InGrid (312691). 


\section{References}

Allison, P. (1999). Comparing Logit and Probit Coefficients Across Groups. Sociological Methods and Research, 28, 186-208. http://dx.doi.org/10.1177/0049124199028002003

Baethge, M., Solga, H., \& Wieck, M. (2007). Berufsbildung im Umbruch - Signale eines überfälligen Aufbruchs. Berlin: Friedrich-Ebert-Stiftung.

Bell, D. N. F., \& Blanchflower, D. G. (2011). Youth unemployment in Europe and the United States. Nordic Economic Policy Review, 1, 11-38.

Blossfeld, H.-P., Buchholz, S., Bukodi, E., \& Kurz, K. (2008). Young Workers, Globalization and the Labor Market. Comparing Early Working Life in Eleven Countries. Cheltenham: Edward Elgar.

Blossfeld, H.-P., \& Shavit, Y. (Eds.). (1993). Persistent Inequality. Changing Educational Attainment in Thirteen Countries. Boulder: Westview Press.

Breen, R., Karlson, K. B., \& Holm, A. (2013). Total, Direct, and Indirect Effects in Logit and Probit Models. Sociological Methods \& Research, 42, 164-191. http://dx.doi.org/10.1177/0049124113494572

Buchholz, S., \& Kurz, K. (2008). A New Mobility Regime in Germany? Young People's Labor Market Entry and Phase of Establishment Since the Mid-1980s. In H.-P. Blossfeld, S. Buchholz \& K. Kurz (2008), Young Workers, Globalization and the Labor Market. Comparing Early Working Life in Eleven Countries (pp. 51-75). Cheltenham: Edward Elgar.

Cahuc, P., Carcillo, S., Rinne, U., \& Zimmermann, K. F. (2013). Youth Unemployment in Old Europe: The Polar Cases of France and Germany. IZA Discussion Paper No. 7490, Bonn.

Dallinger, U., \& Walter, W. (1999). Bericht zur Lage der Generationen. Ifb - Materialien zur Tagung „Erstes, zweites, drittes Lebensalter. Perspektiven der Generationenarbeit" in der Akademie für politische Bildung, Tutzing.

Diewald, M., \& Sill, S. (2004). Mehr Risiken, mehr Chancen? Trends in der Arbeitsmarktmobilität seit Mitte der 1980er Jahre. In O. Struck \& Ch. Köhler (Eds.), Beschäftigungsstabilität im Wandel? (pp. 39-62). München/Mering: Hampp.

Düntgen, A., \& Diewald, M. (2007). Auswirkungen der Flexibilisierung von Beschäftigung auf eine erste Elternschaft. In M. Szydlik (Ed.), Flexibilisierung. Folgen für Arbeit und Familie (pp. 213-231). Wiesbaden: VS Verlag für Sozialwissenschaften.

Erikson, R., \& Goldthorpe, J.H. (1992). The constant flux: a study of class mobility in industrial societies. Oxford: Clarendon Press.

Ermisch, J. F., \& Francesconi, M. (2001). Family structure and children's achievements. Journal of Population Economics, 14, 249-270. http://dx.doi.org/10.1007/s001480000028

European Commission (2009). Communication to the Council on An EU Strategy for Youth - Investing and Empowering. A renewed open method of coordination to address youth challenges and opportunities. $\operatorname{COM(2009)~200.~Brussels,~27.4.2009.~}$

European Commission (2011). Commission Staff Working Document On EU Indicators in the field of youth. SEC(2011) 401. Brussels, 25.03.2011.

Frick, J. R., \& Grabka, M. M. (2003). Imputed Rent and Income Inequality: A Decomposition Analysis for the U.K., West Germany, and the USA. The Review of Income and Wealth, 49, 513-537. http://dx.doi.org/10.1111/j.0034-6586.2003.00102.x

Gebel, M., \& Giesecke, J. (2009). Ökonomische Unsicherheit und Fertilität. Die Wirkung von Beschäftigungsunsicherheit und Arbeitslosigkeit auf die Familiengründung in Ost- und Westdeutschland. Zeitschrift für Soziologie, 38, 399-418.

Giddens, A. (1984). The constitution of society: Outline of the theory of structuration. Cambridge: Polity Press.

Giesecke, J., \& Heisig, J. P. (2011). Destabilization and Destandardization: For Whom? The Development of West German Job Mobility since 1984. Schmollers Jahrbuch. Zeitschrift für Wirtschafts- und Sozialwissenschaften, 131, 301-314.

Giesselmann, M. (2009). Arbeitsmarktpolitischer Wandel in Deutschland seit 1991 und das Working Poor Problem: Einsteiger als Verlierer des Reformprozesses? Zeitschrift für Soziologie, 38, 215-238.

Giesselmann, M., \& Lohmann, H. (2008). The different roles of low-wage work in Germany: regional, demographical and temporal variances in the poverty risk of low-paid workers. In H.-J. Andreß \& $\mathrm{H}$. Lohmann (Eds.), The Working Poor in Europe. Employment, Poverty and Globalization (pp. 96-123). Cheltenham: Edward Elgar. http://dx.doi.org/10.4337/9781848443761.00012

Gottschall, K., \& Bird, K. (2003). Family Leave Policies and Labor Market Segregation in Germany. Reinvention or Reform of the Male Breadwinner? Review of Policy Research - Special Issue on Gender and Work Place Policies, 20, 115 - 134. doi: 10.1111/1541-1338.00007. http://dx.doi.org/10.1111/15411338.00007

Grabka, M. M., Goebel, J., \& Schupp, J. (2012). Höhepunkt der Einkommensungleichheit in Deutschland überschritten? Wochenbericht Nr. 43 des DIW Berlin, Berlin, 3-15.

Grabka, M. M., \& Frick, J.R. (2013). Country case study - Germany. In S. P. Jenkins, A. Brandolini, J. Micklewright \& B. Nolan (Eds.), The great recession and the distribution of household income (pp. 90112). Oxford: Oxford University Press. 
Grabka, M. M., \& Frick, J.R. (2010). Weiterhin hohes Armutsrisiko in Deutschland: Kinder und junge Erwachsene sind besonders betroffen. Wochenbericht Nr. 7 des DIW, Berlin, 2-11.

Groh-Samberg, O. (2013). The New Poverty: Trends and Debates in Contemporary Germany. In L. Raphael (Ed.), Poverty and Welfare in Modern German history. New Perspectives in Current Research, Oxford: Berghahn (in print)

Groh-Samberg, O., \& Voges, W. (2012). Armut und soziale Ausgrenzung. In S. Mau \& N.M. Schöneck (Eds.), Handwörterbuch zur Gesellschaft Deutschlands (pp. 58-79). Springer: VS.

Keeley, B., \& Love, P. (2010). From crisis to recovery. The causes, course and consequences of the great recession. Paris: OECD. http://dx.doi.org/10.1787/9789264077072-en

Kurz, K., Steinhage, N., \& Golsch, K. (2005). Case Study Germany. Global competition, uncertainty and the transition to adulthood. In H.-P. Blossfeld, E. Klijzing, M. Mills \& K. Kurz (Eds.), Globalization, Uncertainty and Youth in Society (pp. 47-79). New York/Oxford: Routledge.

Lenhardt, U., \& Priester, K. (2005). Flexibilisierung - Intensivierung - Entgrenzung: Wandel der Arbeitsbedingungen und Gesundheit. WSI Mitteilungen, 58, 491-497.

Leopold, T., Geißler, F., \& Pink, S. (2011). How Far Do Children Move? Spatial Distances After Leaving the parental Home. SOEP papers No. 368, DIW Berlin.

Mack, J., \& Lansley, S. (1985). Poor Britain. London.

Mayer, K.-U., Müller, W., \& Pollak, R. (2007). Germany: Institutional change and inequalities of access in higher education. In Y. Shavit, R. Arum \& A. Gamoran (Eds.), Stratification in higher education. A comparative study (pp. 240-265). Stanford: Stanford University Press.

Middendorff, E., Apolinarski, B., Poskowsky, J., Kandulla, M., \& Netz, N. (2013). Die wirtschaftliche und soziale Lage der Studierenden in Deutschland. 20. Sozialerhebung des Deutschen Studentenwerks, durchgeführt durch das HIS-Institut für Hochschulforschung, Bonn.

Mood, C. (2010). Logistic regression: Why we cannot do what we think we can do and what we can do about it. European Sociological Review, 26, 67-82. http://dx.doi.org/10.1093/esr/jcp006

Motel, A., \& Szydlik, M. (1999). Private Transfers zwischen den Generationen. Zeitschrift für Soziologie, 28, 322.

Nolan, B., \& Whelan, C. T. (1996). Resources, Deprivation and Poverty. Oxford.

OECD (2011). Divided We Stand: Why Inequality Keeps Rising. OECD Publishing.

OECD (2008). Growing Unequal? Income Distribution and Poverty in OECD Countries. OECD Publishing.

Population Reference Bureau (2013). Fertility Rates in Low Birth-Rate Countries, 1996-2011. Washington: PRB (http://www.prb.org/Publications/Articles/2012/low-fertility-countries-tfr.aspx).

Projektgruppe SOEP (2012). Documentation PGEN. Person-related status and generated variables (v28), Berlin. Available online at: http://www.diw.de/documents/dokumentenarchiv/17/diw 01.c.410636.de/pgenv28.pdf (2.12.2013).

Reinowski, E., \& Steiner, Ch. (2006). Armut von jungen Erwachsenen in der Bundesrepublik. Vierteljahrshefte zur Wirtschaftsforschung, 75, 89-107. http://dx.doi.org/10.3790/vjh.75.1.89

Rinne, U., \& Zimmermann, K. F. (2011). Another Economic Miracle? The German Labor Market and the Great Recession. IZA Discussion Paper No. 6250, Bonn.

Roloff, J. (2010). Informelle und materielle Hilfe-/Unterstützungsleistungen - Wer sind die Akteure? Bevölkerungsforschung Aktuell 06, 12-18.

Scarpetta, S., Sonnet, A., \& Manfredi, T. (2010). Rising Youth Unemployment During The Crisis: How to Prevent Negative Long-term Consequences on a Generation? OECD Social, Employment and Migration Working Papers, No. 106, OECD Publishing.

Scherger, S. (2009). Social change and the timing of family transitions in West Germany. Evidence from cohort comparisons. Time and Society, 18, 106 -129. http://dx.doi.org/10.1177/0961463X08099947

Schulenberg, J. E., \& Schoon, I. (2012). The transition to adulthood across time and place. Longitudinal and Life Course Studies, 3, 164-172.

Smeeding, T. M., \& Phillips, K. R. (2002). Cross-National Differences in Employment and Economic Sufficiency. Annals of the American Academy of Political and Social Science, 580, 103-133. http://dx.doi.org/10.1177/0002716202580001005

Szydlik, M., \& Schupp, J. (2004). Wer erbt mehr? Erbschaften, Sozialstruktur und Alterssicherung. Kölner Zeitschrift für Soziologie und Sozialpsychologie, 56, 609-629. http://dx.doi.org/10.1007/s11577-0040106-0

Townsend, P. (1979). Poverty in the United Kingdom. A Survey of Household Resources and Standards of Living. Harmondsworth.

Wagner, G. G., Frick, J. R., \& Schupp, J. (2007). The German Socio-Economic Panel Study (SOEP) - Evolution, Scope and Enhancements. Schmoller's Jahrbuch - Journal of Applied Social Science Studies, 127, 139ff.

Williams, R. (2009). Using Heterogeneous Choice Models to Compare Logit and Probit Coefficients across Groups. Sociological Methods \& Research, 37, 531-559. http://dx.doi.org/10.1177/0049124109335735 


\section{Endnotes}

${ }^{1}$ Whether the recent years indicate a stop or even reversal of the increase of young adults living with their parents remains to be seen.

${ }^{2}$ However, only a small number of persons possess intermediate or upper general education but no vocational qualifications. Given the higher relevance of vocational qualifications over general schooling certificates for labour market outcomes and thus, poverty, we group individuals that only possess intermediate (upper) general schooling qualifications together with individuals possessing lower (intermediate) secondary school and vocational training.

${ }^{3}$ We do not distinguish between cohabitation and marriage. However, this distinction might be important if cohabiting relationships are perceived as more transient and less likely to involve the pooling of resources.

${ }^{4}$ The precarious labour market segment consists of a variety of jobs marked by low pay and/or insufficient protection and coverage by the social security system. Given that various job schemes have been introduced and abandoned, a detailed description would go beyond the scope of this paper.

${ }^{5}$ Even more extreme is to calculate individual poverty based on the individual earnings of the younger generation even when still living with their parents, see Smeeding and Phillips (2002).

${ }^{6}$ For a general analysis of inter-generational support see Motel and Szydlik (1999), Dallinger and Walter (1999), Roloff (2010); for inter-generational inheritance see Szydlik and Schupp (2004).

${ }^{7}$ Compared to the annual survey of living conditions of university students in Germany, the SOEP underestimates intergenerational transfers. The representative survey for students in Germany reveals that the monthly disposable income of a university student was around the minimum income provided by social assistance. Almost $90 \%$ of students receive economic support from their parents, amounting to around half of their incomes, on average. Students from higher social background have higher incomes than students from lower classes; however, these differences are rather small. In 2012 , the mean income of students was $881 €$ overall, $891 €$ for students from higher social backgrounds and $850 €$ for students from lower social backgrounds. Whereas parental support amounts to $63 \%$ of the income for higher SES students, it makes up only $27 \%$ for lower SES students. The survey also offers detailed descriptions of the material living conditions (housing, income, employment, etc.) of university students in Germany. See Middendorff, Apolinarski, Poskowsky, Kandulla and Netz (2013): 192.

${ }^{8}$ We also estimated logistic regressions and found no substantial differences in findings. A full set of all linear and logit regression models can be found in the appendix. Various approaches have been proposed to allow comparison of coefficients from logit models across different samples (Allison, 1999; Williams, 2009) or after entering additional covariates (Breen, Karlson \& Holm, 2013). However, since we are interested in comparing the coefficients across models with differently measured dependent variables, we follow Mood (2010) in applying LPM models.

${ }^{9}$ To allow proper comparisons, we ran a third set of regressions based on the uncorrected poverty measure, but restricted the analysis to the sample of young adults for whom parental information is available after leaving home. This sample is different from the full sample because we lose those young adults who left home and whose parents quit the sample (see above, section 2). A full table of results for all nine models is given in the appendix.

${ }^{10}$ With this modification we rule out the possibility that those young adults who are considered poor are not on an otherwise promising career path, but truly in a situation of low economic resources and low future prospects. 
